\title{
A New Cytotoxic Naphthoquinone from Paepalanthus latipes
}

\author{
Rodrigo Rezende Kitagawa, ${ }^{a}$ Maria Stella Gonçalves Radd, ${ }^{*}, b$ Lourdes Campaner dos Santos, ${ }^{a}$ and \\ Wagner VILEGAS ${ }^{a}$ \\ ${ }^{a}$ Instituto de Química de Araraquara, Universidade Estadual Paulista "Júlio de Mesquita Filho," Rua Prof. Francisco \\ Degni; s/n, CP 355, 14801-970, Araraquara, SP, Brazil: and ${ }^{b}$ Faculdade de Ciências Farmacêuticas de Araraquara, \\ Universidade Estadual Paulista "Júlio de Mesquita Filho," Rodovia Araraquara-Jaú; Km 1, 14801-902, Araraquara, SP, \\ Brazil. Received July 5, 2004; accepted August 23, 2004
}

\begin{abstract}
Quinones constitute an important class of naturally occurring compounds. They are found in plants, fungi and bacteria. Large number of quinones has been associated with antitumor, antibacterial, antimalarial and antifungal activities. In this work we describe the isolation, structure determination and the cytotoxic index of a new 1,4-naphthoquinone isolated from the capitula of Paepalanthus latipes.
\end{abstract}

Key words naphthoquinone; Paepalanthus; cytotoxicity

Quinones are widely distributed in nature and constitute an important class of naturally occurring compounds. They are found in plants, fungi and bacteria. ${ }^{1)}$ These compounds are aromatic rings with two ketone substitutions. ${ }^{2)}$ Large number of quinones has been associated with antitumor, antibacterial, antimalarial and antifungal activities. ${ }^{3)}$ The antitumor activity is exhibited predominantly by three main groups of naturally occurring quinones such as benzoquinone, naphthoquinone and anthraquinone. Mitomycin and streptonigrin possess $p$-benzoquinone moiety with heterocyclic groups whereas anthracyclines, doxorubicin and daunorubicin consist of anthraquinone moiety. Some naphthaquinone antibiotics such as lapachol and lapinone are also found to be cytotoxic to tumor cells. ${ }^{4)}$

Plants of the Eriocaulaceae family are widespread in the region of the Serra do Cipó, State Minas Gerais, Brazil. Several plants from this family are known as 'everlasting plants' because they appear to be alive even for years after being haversted. Paepalanthus is the largest genus of this family with approximately 500 species. Among there more than 400 species are endemic in Brazil. ${ }^{5)}$ In previous works we have described some biological activity (cytotoxicity, antimicrobial and antioxidant) from naphthopyrones isolated from the capitula of P. bromelioides. ${ }^{6-8)}$

In this work we describe the isolation, structure determination and the cytotoxic effect in vitro of a new 1,4-naphthoquinone isolated from the capitula of Paepalanthus latipes.

\section{Results and Discussion}

Compound 1 was obtained as a red powder. The ES-MS spectrum of 1 (positive mode) exhibited protonated molecular ion $[\mathrm{M}+\mathrm{H}]^{+}$at $\mathrm{m} / \mathrm{z} 317$, corresponding to molecular formula $\mathrm{C}_{16} \mathrm{H}_{12} \mathrm{O}_{7}$. Fragments at $m / z 303\left[\mathrm{M}+\mathrm{H}-\mathrm{CH}_{2}\right]^{+}, \mathrm{m} / \mathrm{z}$ $289\left[\mathrm{M}+\mathrm{H}-2 \times \mathrm{CH}_{2}\right]^{+}$and at $\mathrm{m} / z 285\left[\mathrm{M}-\mathrm{OCH}_{3}\right]^{+}$were also observed. The IR spectrum showed absorptions for hydroxyl $\left(3300 \mathrm{~cm}^{-1}\right)$ and carbonyl groups $\left(1680,1620 \mathrm{~cm}^{-1}\right)$ indicating a para-quinone system. ${ }^{9,10)}$ The complete structure of $\mathbf{1}$ was elucidated by $1 \mathrm{D}$ and 2D NMR experiments at $500 \mathrm{MHz}$. The ${ }^{13} \mathrm{C}-\mathrm{NMR}$ spectrum showed 16 signals. The ${ }^{1} \mathrm{H}-\mathrm{NMR}$ spectrum displayed singlets of aromatic protons at $\delta 6.60$ $(1 \mathrm{H})$ and $6.05(1 \mathrm{H})$. Also evident were signals at $\delta 3.86$ and 3.81 typical of aromatic methoxyl groups. Another signal at $\delta 2.28(3 \mathrm{H})$ corresponds to a methyl group. Assignments of
${ }^{1} \mathrm{H}$ - and ${ }^{13} \mathrm{C}-\mathrm{NMR}$ data were based on HMBC and HSQC experiments (Table 1). In the HMBC spectrum we observed diagnostic long-range correlations between the proton signal at $\delta 6.60(\mathrm{H}-4)$ and the carbon resonances at $\delta 167.0(\mathrm{C}-1)$, 161.4 (C-10), 113.0 (C-10a), 148.0 (C-5) and 20.3 (C-11); the proton at $\delta 6.08(\mathrm{H}-8)$ and the carbonyl carbon resonances at $\delta 177.9(\mathrm{C}-6)$ and at $\delta 189.2(\mathrm{C}-9)$ and the carbon resonances at $160.9(\mathrm{C}-7)$ and $111.2(\mathrm{C}-9 \mathrm{a})$; the proton at $\delta 3.86\left(\mathrm{OCH}_{3}-7\right)$ and the carbon resonance at $\delta 160.9(\mathrm{C}-7)$; the proton signal at $\delta 3.81\left(\mathrm{OCH}_{3}-5\right)$ and the carbon resonance at $\delta 147.9(\mathrm{C}-5)$; the methyl group at $\delta 2.28\left(\mathrm{CH}_{3}-11\right)$ and the carbon signals at $\delta 160.7(\mathrm{C}-3)$ and $\delta 98.2$ (C-4). NOESY experiment displayed correlations between the signal at $\delta 6.60(\mathrm{H}-4)$ and the signals at $\delta 2.28\left(\mathrm{CH}_{3}-11\right)$ and at $\delta 3.81\left(\mathrm{OCH}_{3}-5\right)$, and between the signal at $\delta 6.05(\mathrm{H}-8)$ and the signal at $\delta 3.86\left(\mathrm{OCH}_{3}-7\right)$. On the basis of the above evidence the structure of 1 was established as 5-methoxy-3,4dehydroxanthomegnin (Fig. 1).

Semixanthomegnin is a natural 1,4-naphthoquinone previously isolated from the mould Trichophyton megnini and was recently synthetized in its monochiral form. ${ }^{9}$ Compound $\mathbf{1}$ is the 5-methoxy monomer of the known compound 3,4,3',4'-

Table 1. ${ }^{1} \mathrm{H}$ - and ${ }^{13} \mathrm{C}-\mathrm{NMR}$ Spectral Data of Compound $\mathbf{1}$ ( $\delta$ Values in $\left.\mathrm{CDCl}_{3}\right)$

\begin{tabular}{cccl}
\hline \hline Position & ${ }^{13} \mathrm{C}$ & ${ }^{1} \mathrm{H}$ & $\begin{array}{c}\text { Observed HMBC } \\
\text { correlations }\end{array}$ \\
\hline 1 & 167.0 & & \\
3 & 160.7 & & \\
4 & 98.2 & $6.60(\mathrm{~s})$ & $\mathrm{C} 3, \mathrm{C} 5, \mathrm{C} 10 \mathrm{a}, \mathrm{C} 11$ \\
$4 \mathrm{a}$ & 123.0 & & \\
5 & 147.9 & & \\
$5 \mathrm{a}$ & 143.5 & & \\
6 & 177.9 & & $\mathrm{C} 6, \mathrm{C} 9 \mathrm{a}$ \\
7 & 160.9 & & \\
8 & 109.3 & $6.05(\mathrm{~s})$ & \\
9 & 189.2 & & $\mathrm{C}, \mathrm{C} 4$ \\
$9 \mathrm{a}$ & 111.2 & & $\mathrm{C} 5$ \\
10 & 161.4 & & $\mathrm{C} 7$ \\
$10 \mathrm{a}$ & 113.0 & & \\
11 & 20.3 & $2.28(\mathrm{~s})$ & $3.81(\mathrm{~s})$ \\
OMe-5 & 62.2 & $3.86(\mathrm{~s})$ & \\
OMe-7 & 56.8 & 14.47 & \\
OH-10 & - & & \\
\hline
\end{tabular}




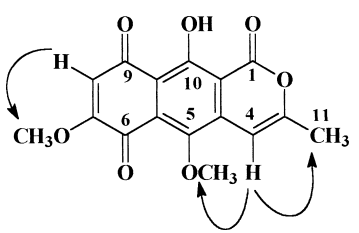

Fig. 1. Chemical Structure of Compound $\mathbf{1}$ with the Observed NOESY Correlations

bisdehydroxanthomegnin, previously isolated from Arthroderma cajetani $\left(=\right.$ Nannizzia cajetani). ${ }^{11)}$

The occurrence of the naphthopyranone derivatives is common to all the Paepalanthus species belonging to the subgenus Platycaulons. The presence of $\mathbf{1}$ in P. latipes is the first description of a 1,4-naphthoquinone in this genus. Compound 1 seems to be biogenetically derived from the acetate pathway through the oxidation at position 6 of the naphthopyranone ring.

Nearly 300 naphthoquinones of different structural types have been isolated from plants, bacteria and fungi. These natural occurring compounds have long been used in folk medicine, and more recent studies have proved the therapeutic value of both natural and synthetic naphthoquinones, particularly as antiparasitic and anticancer agents. ${ }^{12,13)}$

In our study we evaluated the in vitro cytotoxicity of the 1,4-naphthoquinone on McCoy cells using the microculture MTT-tetrazolium assay. ${ }^{14)}$ The new compound showed a significant cytotoxic index of $35.8 \mu \mathrm{g} / \mathrm{ml}$ when compared to cisplatin $\left(\mathrm{CI}_{50}\right.$ value of $\left.41.9 \mu \mathrm{g} / \mathrm{ml}\right)$, a cytotoxic substance used in antineoplasic therapy, used as reference compound on the same cellular system.

The biochemistry and cytotoxicity of naphthoquinones have been extensively studied in vitro. By reaction with cellular reducing agents, naphthoquinones undergo redox cycling, with concomitant formation of reactive oxygen species (ROS) as superoxide anion and hydrogen peroxide. $^{12,15)}$ Furthermore, the carbon atoms adjacent to the carbonyl groups are electrophilic, and naphthoquinones that are not fully substituted in the quinone ring are alkylating agents.

Most chemotherapeutic agents, including alkylating agents, induce cell death in cancer cells by apoptosis. These classes of antineoplastic agents cause cells to over generate ROS, and, thus, are capable of inducing apoptosis, and causing oxidative damage to DNA. ${ }^{16)}$

Quinones have several biological properties and various effects on the different cellular systems. Other biological parameters will be evaluated on anti-cancer potency of this new cytotoxic compound.

\section{Experimental}

General Experimental Procedures NMR spectra in $\mathrm{CDCl}_{3}$ were obtained using a Varian INOVA-500 spectrometer, operating at $500 \mathrm{MHz}$ for ${ }^{1} \mathrm{H}$ and $125 \mathrm{MHz}$ for ${ }^{13} \mathrm{C}$ and 2D-NMR (inverse detect ${ }^{1} \mathrm{H}-{ }^{13} \mathrm{C}$ HSQC and HMBC. ES-MS spectra were performed on a Fisons VG Platform spectrometer in positive $(70 \mathrm{~V})$ mode. The sample was dissolved in $\mathrm{MeOH}$ and injected directly. IR spectrum was performed in a FT-IR-Nicolet Impact IMACT-400, KBr. UV spectra were obtained on a Beckman DU 670 spectrometer. Elemental analysis was made with a Carlo Erba EA 1110 apparatus. TLC were performed on silica gel SiF254 (Merck). The plates were visualized using UV light $(254,365 \mathrm{~nm})$.

Plant Material Paepalanthus latipes was collected in February 1995, at Serra do Cipó, in the Espinhaço Chain, Minas Gerais state, Brazil and authenticated by Prof. Paulo Takeo Sano from Instituto de Biociências, USP,
São Paulo. The voucher specimen (CFSC 13846) is on file of the Herbarium of the Departamento de Botânica, Instituto de Biociências, Universidade de São Paulo, Brazil.

Extraction and Isolation The capitula of Paepalanthus latipes $(180.0 \mathrm{~g})$ were powdered and extracted successively with hexane and methylene chloride. The methylene chloride extract $(5.0 \mathrm{~g})$ was chromatographed on $\mathrm{CC}$ silica gel using a gradient of increasing polarity, starting from toluene-EtOAc 99.5:0.5 and ending with toluene-EtOAc-HOAc 60.0: $39.5: 0.5$. A total of 50 fractions $(100 \mathrm{ml}$ each) were collected and checked by TLC in several eluents [Si gel plates toluene-EtOAc $(5: 5,6: 4,7: 3$, $8: 2,9: 1)$ ]. Fractions 13 and 14 afforded $50 \mathrm{mg}$ of pure 1 .

Compound 1: Red powder, mp $141-144^{\circ} \mathrm{C}$, (toluene-EtOAc 9:1), UV $\lambda_{\max } \mathrm{nm}(\mathrm{MeOH}):(\log \varepsilon) 250$ (4.55); 275 (4.90); 380 (4.00); 420 (3.25); IR $(\mathrm{KBr}) v_{\max } 3300 \mathrm{~cm}^{-1}(\mathrm{OH}), 1680,1620 \mathrm{~cm}^{-1}$ (carbonyl groups). ${ }^{1} \mathrm{H}-\mathrm{NMR}$ $\left(\mathrm{CDCl}_{3}, 500 \mathrm{MHz}\right)$, see Table $1 ;{ }^{13} \mathrm{C}-\mathrm{NMR}\left(\mathrm{CDCl}_{3}, 125 \mathrm{MHz}\right)$, see Table 1; ES-MS $(+70 \mathrm{~V}) \mathrm{m} / z 317[\mathrm{M}+\mathrm{H}]^{+}(30), 303\left[\mathrm{M}+\mathrm{H}-\mathrm{CH}_{2}\right]^{+}$(13), $289[\mathrm{M}+$ $\left.\mathrm{H}-2 \times \mathrm{CH}_{2}\right]^{+}$(17), $285\left[\mathrm{M}-\mathrm{OCH}_{3}\right]^{+}$(12); HR-EI-MS $m / z[\mathrm{M}]^{+} 316.262$. (Calcd 316.270) $\left[\mathrm{C}_{16} \mathrm{H}_{12} \mathrm{O}_{7}\right], 285.0549$ (Calcd 285.0555) [ $\left[\mathrm{C}_{15} \mathrm{H}_{9} \mathrm{O}_{6}\right]$, 254.0838 (Calcd 254.0841) $\left[\mathrm{C}_{14} \mathrm{H}_{6} \mathrm{O}_{5}\right]$. Anal. Calcd for $\mathrm{C}_{16} \mathrm{H}_{12} \mathrm{O}_{7}$ : C, 60.76; $\mathrm{H}, 3.82$; Found: C, 60.76; H, 3.83 .

Test Compound The quinone was obtained from the DCM extract of Paepalanthus latipes and was stored as stock solution at $10.0 \mathrm{mg} / \mathrm{ml}$ in DMSO.

Cytotoxicity Assay McCoy cell line (ATCC CRL-1696b) was maintained in Eagle medium with $7.5 \%$ fetal bovine serum. After trypsinization, $0.2 \mathrm{ml}$ aliquots of medium containing approximately $10^{4} \mathrm{cells} / \mathrm{ml}$ were seeded into 96-well tissue-culture plates and incubated at $37^{\circ} \mathrm{C}$. After $24 \mathrm{~h}$, the Eagle medium was removed and the cells were placed into unmodified medium (control) or in medium modified with various concentrations of test chemical. After incubating for another $24 \mathrm{~h}$, the medium was removed and the plates were prepared for microculture MTT-tetrazolium assay. ${ }^{14)}$ After brief agitation, the plates were transferred to a microplate reader (Spectra and Rainbow (Shell) Readers-Tecan, Austria) and the optical density of each well was measured using a $540 \mathrm{~nm}$ filter and $620 \mathrm{~nm}$ reference wavelength. All experiments were performed at least four times, using three wells for each concentration of chemical tested. The cytotoxicity data was standardized by determining absorbance and calculating the chemical concentration. Linear regression analysis with $95 \%$ confidence limit was used to define dose-response curve and to compute the concentration of chemical agent needed to reduce absorbance of the MTT by $50 \%$, the so called cytotoxic index $\left(\mathrm{CI}_{50}\right){ }^{17)}$

Acknowledgments We thank FAPESP for financial aid to WV, to FUNDUNESP for financial aid to LCS, to CNPq for a fellowship to RRK and for a grant to WV and financial assistance from the PADC-UNESP.

\section{References}

1) Long D. J., Jaiswal A. K., Chem. Biol. Interact., 129, 99-112 (2000).

2) Cowan M. M., Clin. Microbiol. Rev., 12, 564-582 (1999).

3) Huang S., Kuo H., Hsiao C., Lin Y., Bioorg. Med. Chem., 10, 19471952 (2002).

4) Inbaraj J. J., Gandhidasan R., Murugesan R., Free Radic. Biol. Med., 26, 1072-1078 (1999).

5) Giulietti A. M., Hensold N. C., Acta Bot. Bras., 4, 133 (1990).

6) Coelho R. G., Vilegas W., Devienne K. F., Raddi M. S. G., Fitoterapia, 71, 497-500 (2000).

7) Devienne K. F., Raddi M. S. G., Braz. J. Microbiol., 33, 166-168 (2002).

8) Kitagawa R. R., Raddi M. S. G., Vilegas W., Khalil N. M., Fonseca L. M., Biol. Pharm. Bull., 26, 905-908 (2003).

9) Cotterill A. S., Donne C. D., Gill M., White J. M., Aust. J. Chem., 56, 49-57 (2003).

10) Zeeck A., Russ P., Laatsch H., Loeffler W., Wehrle H., Zähner H., Holst H., Chem. Ber., 112, 957-978 (1979).

11) Hill R. A., Chem. Org. Naturst., 49, 1-78 (1986).

12) Munday R., Smith B. L., Munday C. M., Free Radic. Biol. Med., 19, 759-765 (1995).

13) Tandon V. K., Chhor R. B., Singh R. V., Rai S., Yadav B., Bioorg. Med. Chem. Lett., 14, 1079-1083 (2004).

14) Mosmann T. J., J. Immun. Meth., 65, 55-63 (1983).

15) Inbaraj J. J., Chignell C. F., Chem. Res. Toxicol., 17, 55-62 (2004).

16) Lopaczynski W., Zeisel, S. A., Nutr. Res., 21, 295-307 (2001).

17) Barile F. A., "Introduction to in Vivo Cytotoxicology: Mechanisms and Methods," CRC Press, Boca Raton, 1994. 